\title{
The Multiple Faces of the Marmot: Associations with the Plague, Hunting, and Cosmology in Mongolia
}

\author{
Natasha Fijn ${ }^{1}$ (D) Baasanjav Terbish ${ }^{2}$ \\ Accepted: 31 August 2021 / Published online: 13 October 2021 \\ (c) The Author(s), under exclusive licence to Springer Science+Business Media, LLC, part of Springer Nature 2021
}

\begin{abstract}
Mongolians have long known of the association between marmots and the plague. We examine their understanding of the marmot not only as a biological species that can harbour the plague, but also from a cosmological perspective as a chimerical being with potential punishment on hunters who have transgressed ancient taboos. To do so we deconstruct the multiple image of the chimerical marmot in legends, stories, and beliefs. Many Mongolians believe that if the marmot is over-exploited and the population decimated through excessive hunting, hunting households may be punished with infections of the plague.
\end{abstract}

Keywords Marmots $\cdot$ Plague $\cdot$ Cosmology $\cdot$ Hunting $\cdot$ Pastoralism $\cdot$ Mongolia

\section{Introduction}

Like most origin narratives, it is difficult to locate where outbreaks of the plague originated. What we now know is that the plague emerged from the grassland steppes of Central Asia well before historically recorded pandemics, such as the Black Death. There is now evidence that the plague bacteria was present in the Eurasian population during the Bronze Age, from 3800 to 4000 years ago. Near the Volga River in modern day Russia, archaeological researchers extracted teeth from the skeletons of a buried couple who were found to contain the Yersinia pestis bacteria. Even more remarkable, from analyzing the DNA in these ancient teeth, geneticists found the same lineage of bacteria that is transmitted from rodents by fleas to humans today. This indicates that the disease was within the population at least a millennium before the first recorded pandemic (Spyrou et al. 2018: 2). The way of life on the grassland steppes of Eurasia was predominantly nomadic for thousands of years and not generally recorded or written down as text, apart from second-hand accounts from the differing cultural perspectives of their settled neighbours.

Natasha Fijn

Natasha.Fijn@anu.edu.au

1 The Mongolia Institute, College of Asia and the Pacific, The Australian National University, Canberra, Australia

2 Mongolia Inner Asia Studies Unit, University of Cambridge, Cambridge, England
Mongolians made an early connection between marmots and the plague, reflected in the Mongolian name for the plague: 'marmot plague' (tarvagan takhal), or 'disease of marmots' (tarvagany övchin). As early as the eighteenth century, a Mongolian Buddhist scholar, Ye shes dpal 'byor (1704-1788), referred to the bubonic plague as 'marmot poison' (tarvagany khor), a recognition that it was contact with sick marmots that made people ill (Norov 2019: 5). According to Mongolian Buddhist medical tradition, the plague and rabies were categorized as infectious diseases related to a poisoning of the body (dug nad). This connection between marmots and the plague was made by the Mongols long before biomedical scientists conducted observations on the Mongolian Plateau (Preble 1912).

Epidemiologists recognize that close contact with infected Siberian marmots (Marmota sibirica) are significant means for humans to become infected. The plague is caused by the bacteria Yersinia pestis and exhibits in two highly lethal forms - bubonic and pneumonic. If untreated, the mortality rate for the bubonic form is around $60 \%$ and for the pneumonic $100 \%$. The plague is only transmissible between humans in pneumonic form but human to human transmission is rare (Galdan et al. 2010). The bubonic form is transmitted from rodents to humans via infected fleas. Unlike many other zoonotic diseases in Mongolia that are transferred to humans by domestic animals, such as foot-and-mouth, tuberculosis, or brucellosis (Ruhlmann 2018), the plague is transferred from wild animal carriers. In Mongolia the plague is mainly contracted by skinning 
or preparing marmot for cooking, when an individual cuts their hand, or through eating raw infected marmot organs, meat, or fat.

In July 2020, while much of the rest of the world was in lock-down due to the coronavirus pandemic, Mongolia was having to counter outbreaks of the plague. The government implemented quarantine across five regional centres. In Khovd Province in western Mongolia, for instance, a man and a teenage boy were treated in hospital for suspected marmot plague. Both patients fell ill after eating marmots but later recovered. While in an unrelated case, a 15-year-old boy died in neighbouring Govi-Altai Province after eating hunted marmot with two friends. ${ }^{1}$ Between 2012 and 2019, the plague bacteria was prevalent in different kinds of rodent in 137 districts across Mongolia (Kehrmann et al. 2020).

Medical records between 1971 and 2000 indicate that there were 160 registered cases of the plague, of which $90 \%$ were the primary bubonic form. More than $40 \%$ of the cases of bubonic plague developed into secondary pneumonic plague, while the mortality rate during this period was 70\% (WHO 2020). Between 1998 and 2020, there were 73 reported plague cases with 59\% linked to close contact with infected marmots and 7\% from eating raw marmot organs (Kehrmann et al. 2020), clearly indicating links between the hunting and consumption of marmots and the plague in Mongolia.

Scientific research on marmots and the plague is found in epidemiologically-related and zoonosis-related scientific articles (Batbold 2002; Foggin et al. 2000; Galdan et al. 2010; Kehrmann et al. 2020). Scholars have also made connections between the hunting of marmots and the history of the Manchurian Plague on the Mongolian-Manchu border (Gamsa 2006; Lynteris 2013, 2018; Nathan 1967; Teh et al. 1923). However, there has been very little contemporary ethnographic analysis on the connections between the marmot and the plague. Our focus is mainly on marmot hunting and the plague after the end of the Soviet era (post-1990) in Mongolia in the context of state and local community perspectives in relation to hunting, cosmology, and ontology.

Research on the hunting of the marmot in Mongolia has focused mainly on an analysis of commercial hunting, providing data on economic income as part of an illegal trade of wildlife across international borders (see Reading et al 1998; Scharf et al. 2010; Townsend and Zahler 2006; Wingard and Zahler 2006; Zahler et al. 2004). Conservation biologists, Olson and Fuller (2017), for example, conducted a survey on the hunting behaviour of herding households in eastern Mongolia and found that the likelihood and extent of hunting

\footnotetext{
${ }^{1}$ A news article announced that a 15 -year-old boy died of the plague in Govi-Altai Province (Jack and Gansukh 2020). There were also cases emerging around the same time in Inner Mongolia, China.
}

depended upon the number of livestock they had. The fewer herd animals a herder possessed, the greater likelihood that he would hunt as an additional source of household income and subsistence. This study only considered economic factors behind hunting wildlife. However, we found that herders often hunt marmot for non-economic reasons. Taking an anthropological perspective, we provide insights into Mongolian perceptions of the marmot as a being of cultural and historical significance and provide an explanation of why herding communities persist in hunting marmot for household consumption despite government hunting prohibitions and the very real threat of contracting the plague.

We describe Mongolian perceptions of the marmot, both as a biological species that harbours the plague and, from a cosmological perspective, as a spiritual being that spreads the 'disease of marmots' and punishes those who have transgressed taboos. The former is a relatively contemporary scientific knowledge leading to state imposed preventative measures against the plague, while the latter concept of an ancient cosmological being appears in current oral stories that still circulate. These two perspectives of the marmot are not necessarily mutually exclusive in contemporary Mongolian understanding, as the hunting accounts, narratives, and cosmology we describe below indicate.

\section{The Marmot as a Biological Species}

\section{Protection of the Marmot}

According to ancient herding ontology based on the concept of retribution, if the land and nature (baigal) are exploited unnecessarily, the cosmological framework becomes broken and dire consequences will result. Negative actions in one part of the ecosystem are intrinsically interlinked. Soon after Mongolia was transitioning to a democracy and there were significant social and economic changes occurring in the countryside, Humphrey et al. (1993) reported one herder's observations:

"The main animal round here is the marmot. Marmots are being over-hunted these days because the prices of skins are constantly rising. People smuggle bullets from Russia to do this hunting. There have been many cases of plague this year. If we do not treat nature well it will turn against us" (Herder, Uvs Aimag, Mongolia, 1992).

While differing from state and biomedical explanations, this local community interpretation of the relationship between excessive hunting of marmots and the 'marmot plague' is significant, reinforcing as it does herders' belief in the importance of treating this animal with respect.

In the past, marmots were one of the most commonly sighted animals on the Mongolian grassland steppe, but over-hunting has been a long-term problem (Schaller 2020), 
particularly involving full-time hunters who trade marmot pelts over the border with China or Russia (Kolesnikov et al. 2009). Even in the late 1800s, on average the annual trade from Mongolia was over 1.2 million skins, and still exceeded 3 million in the early 2000s (Wingard and Zahler 2006). In the last 60 years alone, there has been a dramatic $75 \%$ decline in the marmot population, resulting in a 'Mongolian marmot crisis' (Townsend and Zahler 2006).

Since the end of the Soviet era, hitherto banned knowledge and practices relating to Buddhism and shamanism have experienced a revival with greater freedom for people to follow their beliefs. Buddhist edicts discourage the killing of living creatures. The spread and commercialization of both Buddhist and shamanic services, however, has enabled hunters to counteract the wrath of the spirits by purchasing protective talismans, or appealing to religious practitioners for ritual protection from potential retribution as a result of their hunting.

Protecting marmots has become increasingly difficult with both urbanites and foreigners traveling to the countryside to indiscriminately kill wildlife with high-powered guns (see Charlier 2015: 14), which make it possible to kill many animals in a short period of time with minimal effort. In 1995, for instance, the price of marmot pelts surged at the same time that gun control laws relaxed in Mongolia (Scharf 2010). The gradual improvement of roads has also enabled hunters to travel long distances by vehicle to hunt remotely rather than the slower pace of traveling on horseback.

In 2006 the government announced a countrywide ban on hunting marmots and by 2012 the protection of the marmot had become part of legislation. That said, there has been little implementation of minimal penalties for the illegal hunting of marmots and other highly sought-after endangered species in remote regions of the country. After assessing marmot numbers, ecologist Susan Townsend (2009) recommended that, although the temporary countrywide ban on hunting in 2006 was viewed as a timely measure, there was still a dramatic decline in the marmot population on the eastern steppe of Mongolia.

Local officials are responsible for enforcing restrictions on herding and hunting, but they are understaffed, underpaid, poorly equipped, and lack adequate government funding (Scharf et al. 2010). Local representative herders are designated 'rangers' within the herding community and issued with khaki uniforms, but their role is symbolic, as the position is unpaid, so there is little incentive for herders to inform authorities to impose fines on others hunting marmots, particularly if the hunter happens to be a close family member.

Proposing solutions to the complex problem of the rampant trade of marmot pelts across international borders, or how state prohibitions could be monitored more effectively in order to sustain the declining marmot population are beyond the scope of this paper. Scharf and colleagues (2010) have recommended some sound potential solutions in relation to the integration of herding and hunting land management strategies at a community level, through the designation of key grazing or wildlife areas, such as marmot colonies, as off-limits to herders or hunters on a rotational basis. This strategy connects with old spatially-oriented systems of conservation, whereby designated mountains are recognized by the herding community as off limits.

Mongolians living in the countryside are aware that vulnerable species are becoming endangered due to over-hunting and that protection of the grassland steppe ecosystem is essential for their own well being as pastoralists (McCarthy et al. 2018). One community-based approach to counteract the disappearance of the marmot is local government programs to reintroduce marmots back into provinces where they have become rare, for example, in Sükhbaatar Province in 2006, 2011, 2012, and 2019 (Montasame News 2019). As a symbol of the marmot's significance, both in terms of cultural heritage and its contribution to the grassland ecosystem today, there are two monuments dedicated to the marmot. One is in the town of Nalaih - a statue of three marmots to commemorate their disappearance (Fig. 1) - the other in Bayan-Uul sum, Dornod Province. ${ }^{2}$

\section{The Marmot and the Plague within Montane-steppe Ecology}

The culturally significant marmot is part of an interconnected ecology encompassing multiple species, including plague bacteria, fleas, predators such as the corsac fox, and Mongolian herding households. As the plague is part of a larger ecosystem, the status of the now endangered marmot impacts upon the virus and the humans who rely on the same system for sustenance and survival (Yoshihara et al. 2009).

It is almost impossible to completely eradicate the plague, even though Mongolia is sparsely populated, as different strains can surface in different species of rodent at any time to become transmissible in humans (Galdan et al. 2010). The intercontinental climate on the Mongolian plateau is dry with extreme temperature fluctuations, resulting in a unique relationship between the tarvaga marmot (Marmota sibirica) and a parasite, the flea (O. silantiewi) (Fig. 2), while the aridity of the climate also produces favourable conditions for the adaptation of the plague bacteria ( $Y$. pestis). According to Suntsov (2017), the bacteria adapted to the hibernation of marmots, who plug up their burrow with soil, organic matter, and their own faeces. During hibernation (generally from October-November until March-April, depending on

\footnotetext{
2 The organizations behind the placement of the statue in Bayan-Uul. Accessed 07/14/2020. https://montsame.mn/en/read/130265.
} 
Fig. 1 Marmot memorial statue, Nalaih. Photo courtesy of Christian Sorace

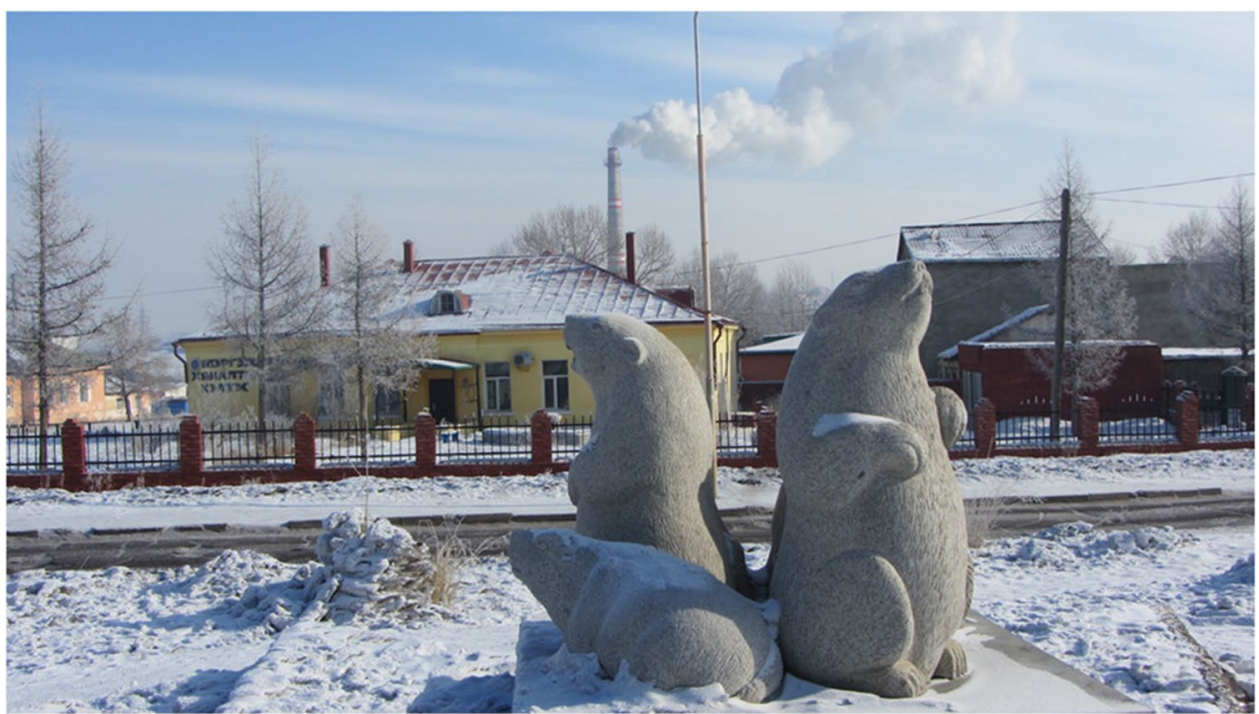

seasonal conditions), marmot flea larvae damage the skin around the mouth, eyes, and anus of the animal to feed on the blood. When a flea ingests $Y$. pestis, the plague bacteria multiply, blocking the gastrointestinal tract, causing fleas to disgorge some of the bacteria into any mammal they bite (Orloski and Lathrop 2003).

Despite carrying plague bacteria, marmots have been identified by ecologists as a 'keystone species' in their largely intact forest-steppe habitat in Mongolia, where their presence assists the survival of other species, while they are also viewed by some as bellwethers for climate change (Townsend 2009). Consequently, a decline in marmot numbers results in a cascade effect on other species, both plant and animal, within the grassland ecosystem. Yoshihara and colleagues (2009) observed that marmots help maintain plant diversity, as well as the persistence of forb species.

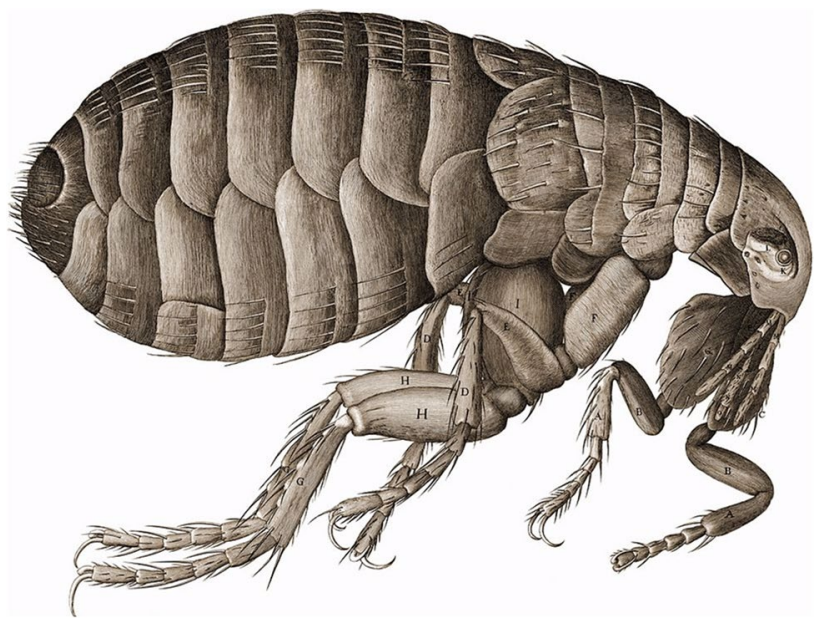

Fig. 2 Robert Hooke's early taxonomic drawing of a flea, 1665 (public domain)
Insects, beetles, and bees were found to be more abundant where there were marmot burrows, and are therefore vulnerable to changes in marmot population size. Marmots are also important prey for carnivores, such as foxes and polecats, as well as raptors.

Marmots physically structure their grassland habitat through their burrowing, occasionally with more than 90 entrances in large colonies. The burrows provide important shelter for a wide range of species, including mesocarnivores such as the corsac fox, pallas cat, and red fox, as well as hedgehogs and a range of reptiles and insects. Murdoch and colleagues (2009) also found that marmot burrows provide refuge for corsac foxes from larger predators, such as wolves or dogs.

The plague can remain dormant within marmot burrows for over a year, and can be distributed among burrows across different colonies through the movements of predators, particularly corsac foxes. It is notable that corsac foxes, Siberian polecats, and mountain weasels have all been found infected by plague, probably contracted from entering and sometimes sheltering in marmot burrows (Galdan et al. 2010).

It is evident, then, that the plague is part of a much larger, interconnected ecosystem in which mobile pastoral communities also play a part. Extinction of the Siberian marmot would have cascade effects throughout the grassland steppe, one of the few remaining extensive grassland ecosystems in the world and home to wild mountain sheep and goats, camels, wild ass, as well as predators such as wolves, bears, and snow leopards (Scharf 2010).

\section{Countering the Plague}

All zoonotic diseases, including the marmot plague, are researched and monitored in Mongolia by the National 
Center for Zoonotic Diseases in the capital city of Ulaanbaatar, with separate branches across 13 of its 21 provinces. The National Center was founded as the Marmot Plague Control Laboratory in 1931 and was initially run mainly by Soviet doctors and technicians. (In the same era, over 2 million marmots were hunted and shot annually according to government-imposed harvest quotas (Saveljev et al. 2014)). Having changed its name several times over the years with increasing responsibilities and the growing recognition of the importance of zoonotic diseases worldwide, the organization acquired its current name in $2012^{3}$ and continues epidemiological, bacteriological, and clinical medicine research in relation to the plague. Scientists carry out regular field trips and use mobile laboratories for the education of rural communities in order to increase awareness of the plague. ${ }^{4}$

The state level response to the plague is in alignment with international biomedical-based responses to zoonotic diseases. A scientific framework has also been developed to immediately lock down any provinces or regions with a proven plague outbreak, to quarantine anyone in contact with someone who has contracted the plague, and treat patients in regional hospitals with antibiotics. According to government directives, all hospitals across the country, especially those in provinces with known risk of plague outbreaks, are required to isolate and treat patients under the required plague infection control regime. ${ }^{5}$ Today, with the growing number of incidents of people caught trying to bring marmot meat illegally into Ulaanbaatar, the city municipality together with the National Centre for Zoonotic Diseases periodically set up checkpoints to inspect all vehicles on the outskirts of the capital until the end of each autumn, coinciding with the end of the marmot hunting season.

After finding that young men aged 19-25 were most commonly infected after hunting and skinning marmots, Mongolian scientists based at the National Centre stated: 'The most effective way to reduce the rate of infection among marmot hunters is to increase their awareness of the plague infection risks associated with contact with marmots and other rodents and to educate them on ways to prevent plague infection' (Galdan et al. 2010). This has also been supplemented by a vaccination program. In April-May 2019, a hunter who had

\footnotetext{
3 This institution has experienced many name changes, often with restructuring due to political changes: The Marmot Plague Control Centre in 1940; the Institute for the Control of Infectious Diseases in 1961; the Institute for the Control of Natural Outbreaks in 1990; the National Center for the Study of Natural Outbreaks in 2006; and the National Centre for Infectious Diseases with Natural Foci in 2010.

${ }^{4}$ National Centre for Zoonotic Diseases website (in Mongolian). Accessed 07/15/2020. https://nczd.gov.mn/?page_id=2243.

5 See the Legal United Information System website (in Mongolian). Accessed 07/14/2020. https://www.legalinfo.mn/annex/details/4463? lawid $=8318$. The link to the page is entitled 'Instructions for Measures to Fight against the Marmot Plague.'
}

been vaccinated with an EV76 $Y$. pestis vaccine one year previously, died after eating raw marmot organs, which suggests that the vaccine does not necessarily provide people with long-lasting immunity (Kehrmann et al. 2020: 18781879). The perceptions of the plague beyond state institutions in pastoral communities in the Mongolian countryside, however, are based on quite different ontological and cosmological frameworks.

\section{The Chimerical Marmot in the Mongolian Landscape}

\section{Hunting the Marmot}

The marmot has traditionally been hunted for three main reasons - its pelt, as meat, and organs as a traditional form of medicine. As we noted above, marmots are highly prized for their pelts, which are sold across international borders to provide monetary income. We focus here on the tradition of the marmot as an alternative food for Mongolian pastoralists rather than for economic gain.

Marmot meat is considered a delicacy and Mongolian herding males find it hard to resist hunting a marmot if they see one. The most common method of cooking marmot is boodog, a process of placing stones in embers and then placing the heated stones into the marmot's stomach cavity with the surrounding fat (Fig. 3). Apart from its flavour, which is greatly savoured, marmot meat is thought to have powerful medicinal properties. There are many stories passed on within herding communities of individuals recovering from all sorts of life-threatening diseases by consuming marmot organs (see Fijn, forthcoming).

Across the Mongolian Plateau, archaeological evidence from a number of different sites spanning thousands of years, from as far back as the Neolithic, indicates that marmots have long been hunted as an important food source (Khenzykhenova et al. 2016; Masuda et al. 2015). In Mongolian historical documents, marmot was mentioned as food in the thirteenth century foundational text, The Secret History of the Mongols, in which Chinggis Khan (known as Tumüjin as a child) and his family are described as having survived on hunted marmots in particularly bad conditions after their tribe abandoned them following the sudden death of his father. The Yüan shi, the dynastic history of the Mongols, composed in 1370 in the Ming court, notes that during the Yüan dynasty in China, the Emperor built ancestral temples in Peking where offerings included marmots with other wild animals (Jagchid and Hyer 1979: 38, 40, 45). Prior to the use of Russian-made guns, hunters relied on the bows and arrows, sometimes firing their quarry from horseback, or used hand-held weapons, such as the bolo, to club small mammals such as marmots (Braae 2017: 443-444). 




Fig. 3 Boy preparing marmot for cooking. Photo credit: Mark Heard, 2001 (CC BY-NC 2.0)

Hunting predominated in the forested and mountainous terrains of northern and western Mongolia, where animals with thick pelts, including the Siberian marmot, were more abundant. In rural communities, knowledge surrounding the hunting of marmots is passed from father to son. Hunting marmots is seasonal during late summer and into autumn, when marmots are heavier and 'fatter' in preparation for hibernation. Dogs, chosen for their skill in burrowing, may be used to assist in hunting.

Many hunters have containers or homemade vessels (anchny ongon) to attract spirit deities to sanction the hunting of marmots and protect the hunter and his household from the wrath of powerful protector deities for killing other beings living on the land (Pedersen 2007: 158-159). The hunter may also drip blood from the hunted marmot onto his gun, a means of incorporating the life force of the prey onto the weapon, in order to assist the fortune (hishig) of future hunts (Charlier 2015). Hunted marmots are often carried back to the yurt to be cured by inserting a small hole in each lower lip so that several can be hung from the saddle of a horse or motorbike at once.

The Russian scholar, Sevyan Vainshtein (1979: 182) observed men hunting in Tuva (which borders Mongolia to the south and of which it was a part until 1911) wearing a special hunting costume consisting of a white jacket made from the coat of goat or roe deer, a cone-shaped hat with ears or horns, similar to the silhouette of the ears of a mammal and designed to initially startle the sentinel marmot while a stick with fine white hair on the end is twirled and jerked in an alluring manner to ensure that the curious marmot remains still enough for the hunter to aim and fire his rifle. ${ }^{6}$ These hunting costumes have been found in Siberian rock engravings of the Paleolithic era, indicating that this hunting technique must be very ancient indeed (Jacobson-Tepfer and Meacham 2010: 49, Fig. 3.38; Vainshtein 1979: 182).

Pegg observed the hunt as a marmot 'dance' ('to make the marmot joyous,' tarvaga höörü̈leh) in Hovd Province, western Mongolia in 1989, where the hunter was 'making circular movements with a white yak's brush to beckon (dallaga) the marmots.' She describes the dance steps as imitating the trotting movement (shogshilt) of a wolf or a dog. 'Marmots lured from their burrows, especially the young ones that were very curious, all sat on their hind legs to watch. The hunter was thus able to get close to the animals - within 20-30m - and to select those that were both mature and had good quality pelts' (Pegg 2001: 246). By mimicking the movements of a (usually herbivorous) animal, such as a goat, deer, or antelope, or a predator such as a wolf, the hunter can approach the marmot. Whilst this technique is still used today by some hunters, many choose to shoot the marmot directly.

The hunting of marmot, as with other wild animals, is often only a sporadic and occasional pastime and an exciting distraction from the day-to-day care of domestic herd animals. Marmots burrow in the open pasture, so are observed by herder when directing the sheep and goat herd, or when searching for stray horses or cattle. We now turn to how both hunters and marmot colonies could be viewed as sentinels for the plague.

\section{Mongol Hunting Knowledge}

Mongol hunters have long known about the disease associated with the marmot from both oral and practical knowledge passed down over the generations (ardyn erdem uhaan) and can identify subtle signs of illness exhibited by individual marmots. This knowledge includes a test as to whether a

\footnotetext{
${ }^{6}$ For an early account of the way Mongolians hunt marmot, also see Curruthers and Miller (1914). To view how the marmot hunt is carried out, see Thomas Winston's film (2011).
} 


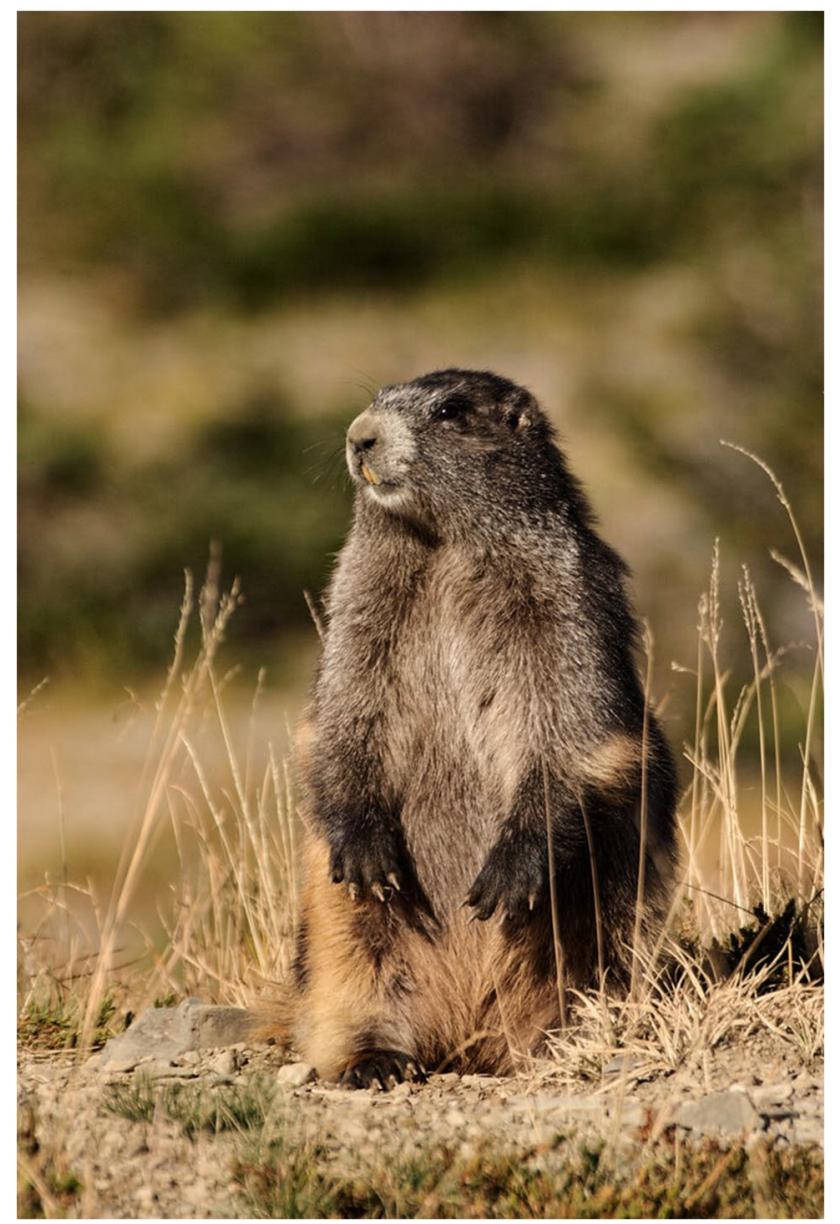

Fig. 4 A healthy sentinel marmot (tarvaga). Photo: Rick Cameron (CC BY-NC-ND 2.0)

marmot has the disease by pricking the paw of the marmot after it has been shot. ${ }^{7}$

Hunters also observe the behavior of sentinel marmots (Keck 2020), who act as lookouts at the burrow exit, alerting the rest of the colony to approaching predators or other dangers (Fig. 1). Their role is twofold in the sense that they are able to communicate not only to their colonies but also alert Mongolian hunters about the spread of disease through signs of illness (Fig. 4). If a sentinel marmot does not make a loud warning call to the rest of the colony and is seemingly unaware of any danger, or appears sluggish with slow

\footnotetext{
${ }^{7}$ In observations of Mongols hunting in Manchuria (now Inner Mongolia), Farrar noted at the beginning of last century: 'If the blood is coagulated and does not flow readily, the animal is regarded as diseased and given to the dogs, which are said not to suffer from eating it' (Farrar 1912, 5). Mongolian mobile pastoralists use bloodletting as a means of healing herd animals and have a good knowledge of whether an animal is healthy, based on the colour and viscosity of the blood (see Fijn 2020).
}

or unsteady movements, this indicates to the hunter that it may be diseased and is to be avoided. A marmot crossing the grassland steppe on its own, rather than remaining near burrows, is another sign that there is something wrong. According to oral stories, when a marmot colony becomes sick, an individual marmot sets out on a journey to bring minerals or medicinal plants back to the colony. Such marmots are not to be hunted (see Bawden 2004: 537).

Some may dismiss these well-known Mongolian signs and stories with regard to the plague as metaphorical morals providing insights into the human condition, yet as Rane Willerslev (2007) and Paul Nadasdy (2007) have argued, we should take such accounts seriously: 'our refusal to consider aboriginal accounts of hunting as perhaps literally as well as metaphorically valid has both contributed to the marginalization of aboriginal peoples and foreclosed important avenues of inquiry into hunting societies and the nature of human-animal relations' (Nadasdy 2007: 25). In the Mongolian context, these signs and stories are important and have real life consequences, not least because they guide human interaction in relation to the marmot and the 'disease of marmots.'

Knowledgeable hunters (those who have ardyn erdem uhaan) are alert to behavioural or physiological indications of illness exhibited by marmots. Living as a mobile pastoralist means that herders are attuned to lethargy or other bodily signs of illness in their herd animals from their daily interactions (Fijn 2020). Observations of signs of the plague in the marmot population will not necessarily result in hunters notifying government authorities, however, particularly since marmot hunting is now illegal. One such example was a woman who had symptoms of the plague with her husband critically ill in hospital, who did not want to admit to authorities that she had consumed raw marmot organs. She subsequently died from the plague, leaving behind four young children (Kehrmann et al. 2020).

Mongolians who hunt and eat marmot are the main link between sick marmots and the plague within the human population. These individuals may benefit the community as their knowledge about the marmot may help to track sites of emergence of the plague, yet if they become infected they may also be blamed by the public for spreading the plague through persisting in hunting and consuming marmot.

\section{Chimerical Beings}

The marmot is an animal that could be thought of as occupying a liminal zone between the human domestic world and the 'wild' and this is reflected in Mongolian cosmology. Discussing the Innu people and their relationship with the caribou reindeer in Canada, Mario Blaser (2016) argues that the caribou are perceived quite differently by Innu hunters and wildlife managers working within the provincial 
government. The former call the reindeer $a t^{\wedge} l k u$ 'a nonhuman person that has will' and in contrast the latter call reindeer caribou 'an animal driven by instincts' altogether different beings (2016: 557).

Similarly, according to Mongol legend (which has several versions, see Potanin 1883: 179-180), the marmot originated from a human - a skillful archer named Erkhii Mergen, who after failing to shoot down the sun, cuts off his thumbs and turns into a marmot, retreating to live underground. Hence the marmot has four fingers and lives in burrows, while some of its body parts are referred to as hün mah, meaning 'human meat.' Whilst a known carrier of the dangerous 'disease of marmots,' marmot meat and body parts are also believed to have powerful healing or protective properties and have been used as a cure for illnesses as part of Mongolian medicinal practices (see Fijn forthcoming). Unlike the $a t^{\imath} \imath k u$, which has essentially one form (in that, according to Blazer (2016), the being looks like a reindeer), the marmot has several cosmological forms.

The notion of a chimera is helpful in further clarifying the marmot's cosmological forms. The word 'chimera,' a Greek term, refers to an image of a single body constituted from different elements. In his book The Chimera Principle (2015), anthropologist Carlo Severi uses the term chimera to describe religious images and objects. According to him, a chimera is 'an association, within one single image, of the heterogeneous features of a number of different beings' (2015: 67). Unlike the Greek mythological chimera, which has a monstrous body combining various animal parts, the Mongolian marmot resembles Severi's conception of chimera in the sense that it can be described as an association within one symbolic image, through the heterogeneous features of a number of different beings.

Multiple forms or aspects of the marmot are vividly revealed through special stories (bolson yavdal) and legends in which the marmot figures: as an actual living marmot; as a Marmot Lord (Noyon Tarvaga); as a 'marmot person' (tarvagan hün); and as a nonhuman spirit being (lusyn am'tan). These multiple aspects of what Mongolians perceive when they think of the marmot do not organically turn into one another (in other words, shape-shift), nor do they directly communicate with each other in a cosmological sense. The image of the marmot embodies fantastical, as well as physical aspects of this animal. To perceive its different aspects or forms, one needs to deconstruct the chimera-marmot with the help of legends, bolson yavdal stories, including Buddhist and shamanic elements, all of which portray the marmot as a representative of multiple supernatural forms.

Let us explain this point with the help of bolson yavdal (lit. 'stories that really happened'), which constitute a special genre of narrating particularly unusual events that happened in the near past and are credited as having living witnesses (Humphrey 2018). Bolson yavdal convey strong moral messages in that the protagonists are always those who have transgressed ancient taboos or have done something wrong. It is not only the transgressor who is punished by offended spirits for their misdeed, but includes whole families, which reflects Mongolian social organization centered around patrilineages.

The following bolson yavdal story is said to have occurred during the socialist period in a location with abundant marmots and is about one man who presumably killed a Marmot Lord (Noyon Tarvaga, who is a 'Huge Marmot' deity and viewed as protector of marmot colonies). One day a man went marmot hunting. Having killed several marmots, the man could not believe his luck and decided to continue killing as many animals as he could. He shot dead one marmot after another, all the while wondering whether he could shoot the local Marmot Lord. Finally, he saw a huge marmot - the size of a big dog - sticking its head just out of a burrow and sent a bullet right through its forehead. Triumphant with success, the man returned home, only to see his children fall ill one after another. In a panic, he rushed to his neighbor, who was a clairvoyant (mergen hün). On the advice of the clairvoyant, the man prepared a marmot carcass, filled it with carefully prescribed material, and went to perform a magical ritual at the spot where he had shot the Marmot Lord. It was only after he performed this specific ritual that his children recovered.

Many Mongols also believe in the existence of 'marmot persons' (tarvagan hün). The expression tarvagan hün has two meanings. First, it refers to diminutive people. Second, it denotes mythical 'tiny' people believed to be the same size as an actual marmot. In bolson yavdal stories 'marmot persons' live underground in places of spiritual significance, sometimes ride tiny horses, wear traditional dress, and protect ancient treasures. Whilst stories about marmot persons have always been popular among herding communities, a prominent story was reported on the national news within an evening broadcast in 1991. The news item sparked particular interest as it was the first time that such a story, hitherto denied by the socialist state as superstition, was acknowledged on national television. The rumour first circulated among local truck drivers but quickly spread to the wider population (see Humphrey 2018). Initially spotted by a truck driver, the diminutive 'marmot person' allegedly ran across the road in front of his truck, clad in a Mongolian robe, wearing a traditional hat, and jumped down a burrow on the roadside. The place, called Zaisan Tolgoi, on the outskirts of Ulaanbaatar turned into a site for mass gatherings of curious onlookers. Workers began to leave offices and pupils skipped school just to catch sight of this 'marmot person.'

The next bolson yavdal story allegedly happened in western Mongolia during the socialist period. One day a man who had not eaten meat for a long time felt a strong desire to taste some marmot meat. In the Mongolian language, 
there is even a word for this feeling - mahsah, derived from the word mah or 'meat.' After a long horse ride, he arrived at a mountain slope known for its abundance in marmots. Despite being warned by his friends not to hunt around that particular mountain, the man, who was a communist and had adopted Soviet values, ignored the decree to not hunt there as superstition and, smiling in anticipation of a delicious meal, pointed his rifle at what he saw as squeaking barbeque (boodog) on four legs. Whenever he was about to pull the trigger of his rifle, however, his vision blurred and he saw a huge, hazy black hand cover the marmot. After several further attempts with the same vision occurring each time, the man panicked and galloped home. At night he had terrible nightmares. The next morning, he consulted a local elder, who was a lama in his youth. After listening to the story, the elder said, 'It is good that you have not killed any marmots because what you saw was the spirit lord (gazryn ezen) of the sacred mountain that was protecting its animals. But now that you have angered the deity, it will come after you and your family. Before it is too late, take your family and move elsewhere where the lord won't get you.' Worried and shocked, the man did what he was told by the lama. In the new place, his nightmares ceased and his life returned to normality. These kinds of story are very popular across Mongolia (see Altangerel 2006).

According to ancient Mongolian cosmology, natural calamities, misfortune, and disease are considered symptoms of the inappropriate actions of individuals, who have offended powerful spirit beings. To prevent misfortune or disease from occurring in the first place, Mongolians try to keep the cosmological equilibrium in balance. In the case of 'marmot disease' prevention, this encompasses: the acknowledgement of the existence of retributive spirits that send disease; a reverence for the marmot's connection with powerful invisible forces (gazryn ezed); an awareness of the powerful medicinal and protective qualities of marmot organs and body parts; an awareness of different kinds of cosmology in relation to marmots; and the importance of killing no more living marmots that one needs to avoid further retribution.

\section{Conclusion}

The marmot, as a biological species with the plague, is constructed through scientific, political, and economic categorization from the perspectives of zoologists, ecologists, epidemiologists, and medical specialists at the National Center for Zoonotic Diseases, police checkpoints implementing plague isolation protocols; whereas the chimerical marmot emerges from a complex assemblage that involves quite different aspects, including knowledgeable hunters, spiritual powers, taboos, Mongolian medicine rites, and a reverence for mother earth. The marmot's cosmological position entailing respect towards this significant species is likely to have been one of the cultural factors in the marmot's survival on the montane-steppe grasslands of Mongolia.

The marmot is a special case in Mongolian mobile pastoral ontology in that it is perceived as a chimerical being that can simultaneously be an animal, a spirit being, a mythical tiny person, and a human-turned-burrow dwelling animal. For Mongolians, you never know which of these forms you will encounter when you see a marmot. The marmot's chimerical nature stems from a liminal position as a being that is both 'wild' and close to humans with some of its body parts referred to as 'human meat' (hün mah).

During the socialist era, however, Mongolians were actively required to dispense with long-held hunting taboos and the spiritual repercussions of indiscriminately killing marmots. In the adoption of scientific paradigms, the marmot was shed of its multi-layered chimerical skin and began to emerge as a biological species, which included viewing the species as a commodity to be utilized in the financial strengthening of the state. Whilst hunting by individuals has been practiced for thousands of years, today's problem of the over-killing of marmots is orchestrated by the invisible hand of the market economy and large-scale illegal trade across international borders, endangering the very survival of the marmot.

The revival of spiritual beliefs in recent years saw a re-emergence of some of the multiple chimerical faces of the marmot. Believing in the marmot plague and its sci-entifically-derived vaccination, symptoms, and antibioticbased treatment, does not stop many Mongolians also believing in the spiritual powers and underlying cosmological significance of the marmot. The marmot is contradictory for Mongolians in another sense, in that despite government prohibitions, herding families still persist in eating marmot as a delicacy, not least because it is permissible from the perspective of cosmology and thought of as containing powerful medicinal qualities. As long as one does not poach or kill marmots in sacred places, hunting marmots for consumption as a delicacy within the family household has been retained as a part of the way of life in Mongolian herding communities.

We have only scratched the surface in terms of Mongolian knowledge and perceptions surrounding marmots and the plague. Further archival and ethnographic research is necessary in terms of establishing stronger links between herders hunting marmots, the supply chains in the trading of marmots, and the annual occurrence of plague in Mongolia. Progress could be made if knowledgeable and observant herders were acknowledged as being capable of acting as sentinels for the plague through their intergenerational knowledge and attunement to marmot behaviour and habits. Herding families and the marmot as carriers of the plague bacteria make 
up important components of an interconnected multispecies, montane-steppe ecology on the Mongolian plateau.

Acknowledgements Natasha Fijn's research and fieldwork was funded by an Australian Research Council grant (DP190103110, 2019-2022) and an earlier Fejos Fellowship from the Wenner-Gren Foundation in 2017. She would like to thank the Mongolian herding communities in Arkhangai and Bulgan Provinces who collaborated in this field research and were willing to convey aspects of their valuable knowledge. Baasanjav Terbish would also like to thank Caroline Humphrey for a discussion surrounding the Mongolian marmot as a 'chimerical' being. Thank you to the anonymous reviewers for their invaluable comments and to Benedikte Lindskog, Li Narangoa and Tom White for their feedback on an earlier version of the manuscript.

\section{References}

Altangerel, Damdinsurengyn. 2006. Mongolian Folktales and Legends. Ulaanbaatar: Sodpress.

Batbold, Jamsrangiin. 2002. The problems of management of marmots in Mongolia. In Holarctic Marmots as a Factor of Biodiversity, Proceedings of the Third International Conference on Marmots, Abstracts, edited by K. B. Armaitage and V. Y. Rumiantsev, 68-75. Cheboksary.

Bawden, Charles R. 2004. Mongolian Traditional Literature: An anthology. London: Kegan Paul.

Blaser, Mario. 2016. Is another cosmopolitics possible? Cultural Anthropology 31: 545-570.

Braae, Christel. 2017. Among the Herders of Inner Mongolia: The Haslund-Christensen Collection at the National Museum of Denmark. Aarhus: Aarhus University Press.

Charlier, Bernard. 2015. Faces of the Wolf: Managing the Human, NonHuman Boundary in Mongolia. Leiden \& Boston: Brill.

Curruthers, Donald and Jack H. Miller. 1914. Unknown Mongolia: A Record of Travel and Exploration in North-West Mongolia and Dzungaria Volume II. London: Hutchinson \& Co.

Farrar, Reginald. 1912. Plague in Manchuria. Proceedings of the Royal Society of Medicine 5: 1-14.

Fijn, Natasha Forthcoming. Marmots, Medicine and the Plague in Mongolia. Études mongoles et sibériennes, centrasiatiques et tibétaines.

Fijn, Natasha 2020. Bloodletting in Mongolia: Three visual narratives. In Fluid Matter(s): Flow and Transformation in the History of the Body, edited by N. Kohle and S. Kuriyama. Canberra: ANU Press. https://doi.org/10.22459/FM.2020.

Foggin, Peter M., Marc J. Foggin, and C. Shiirev-Adiya. 2000. Animal and human health among seminomadic herders of Central Mongolia: Brucellosis and the bubonic plagues in Ovorhangay aimag. Nomadic Peoples 4: 148-168.

Galdan, Bolormaa, et al. 2010. Plague in Mongolia. Vector Borne and Zoonotic Diseases 10: 69-76.

Gamsa, Mark. 2006. The epidemic of pneumonic plague in Manchuria 1910-1911. Past and Present 190 (1): 147-183.

Humphrey, Caroline. 2018. The fateful landing of the hoopoe: Omens from the world. Terrain. Accessed 07/12/2020. https://doi.org/10. 4000/terrain. 16579 .

Humphrey, Caroline, Marina Mongush, and B. Telengid. 1993. Attitudes to nature in Mongolia and Tuva: A preliminary report. Nomadic Peoples 33: 51-61.

Jagchid, Sechin, and Paul Hyer. 1979. Mongolia's Culture and Society Folkstone: William Dawson Ltd.
Jack, Guy and Biligdemberel Gansukh 2020. Teenage boy dies from eating bubonic plague after eating marmot. $C N N$ World Accessed 07/20/2020. https://edition.cnn.com/2020/07/15/asia/mongoliaplague-death-scli-intl/index.html.

Jacobson-Tepfer, Esther and Meacham, James E. 2010. Archaeology and Landscape in the Mongolian Altai: An atlas. New York: ESRI Press.

Keck, Frederic. 2020. Avian Reservoirs: Virus Hunters and Birdwatchers in Chinese Sentinel Posts. Durham: Duke University Press.

Kehrmann, Jan, Walter Popp, Battumur Delgermaa, Damdin Otgonbayar, Tsagaan Gantumur, Jan Buer, and Nyamdorj Tsogbadrakh. 2020. Two fatal cases of plague after consumption or raw marmot organs. Emerging Microbes \& Infections 9 (1): 1878-1880.

Khenzykhenova, Feodora et al. 2016. New data on small mammals of Neolithic sites and burial grounds in Mongolia. Erforsch. Biol. Ress. Mongolei 13: 333-339.

Kolesnikov, Viacheslav V. et al. 2009. Factors that lead to a decline in numbers of Mongolian marmot populations. Ethology, Ecology \& Evolution 21: 371-379.

Lynteris, Christos. 2013. Skilled natives, inept collies: Marmot hunting and the great Manchurian pneumonic plague (1910-1911). History and Anthropology 24: 303-321.

Lynteris, Christos. 2018. Ethnographic Plague: Configuring Disease on the Chinese-Russian Frontier. London: Palgrave MacMillan.

Masuda, Riuichi et al. 2015. Ancient DNA analysis of marmot tooth remains from the Shamanka II and Lokomotiv-Raisovet cemeteries near Lake Baikal: Species identification and genealogical characteristics. Quaternary International. Accessed 04/16/2020. https://doi.org/10.10116/j.quaint.2015.03.050.

McCarthy, Christopher et al. 2018. Assessing local Indigenous knowledge and information sources on biodiversity conservation and protected area management at Khuvsgol Lake National Park, Mongolia." Land 117. Accessed 05/16/2020. https://doi.org/10.3390/ land7040117.

Montsame News 2019. Mongol tarvaga sergeen hutagshuulah aglig ehlü̈̈llee. 13 June 2019. Accessed 07/14/2020. https://www. youtube.com/watch? $\mathrm{v}=$ SOEGyRnUCdU.

Murdoch, James D. et al. 2009. The endangered Siberian marmot Marmota siberica as a keystone species. Observations and implication of burrow use by corsac foxes Vulpes corsac in Mongolia. Oryx 43 (3): 431-434.

Nadasdy, Paul. 2007. The gift of the animal: the ontology of hunting and human-animal sociality. American Ethnologist 34: 25-43.

Nathan, Carl F. 1967. Plague Prevention and Politics in Manchuria 1910-1931. Cambridge: Harvard East Asian Monographs.

Norov, Batsaikhan. 2019. Mongolian Buddhist scholars work on infectious diseases (late $17^{\text {th }}$ Century to the beginning of the $20^{\text {th }}$ Century). Religions 10 (4): 229. doi:https://doi.org/10.3390/ rel10040229.

Olson, Kirk A., and Todd K. Fuller. 2017. Wildlife hunting in eastern Mongolia: Economic and demographic factors influencing hinting behavior in herding households. Mongolian Journal of Biological Sciences 15 (1-2): 37-46.

Orloski, Kathleen A., and Lathrop Sarah L. 2003. Plague: a veterinary perspective. JAVMA 222 (4): 444-448.

Pedersen, Morten A. 2007. Multiplicity without myth: Theorizing Darhad perspectivism. Inner Asia 9: 311-328.

Pegg, Caroline. 2001. Mongolian Music, Dance and Oral Narrative: Performing Diverse Identities. Seattle \& London: University of Washington Press.

Potanin, Grigory N. 1883. Ocherki Severo-Zapadnoi Mongolii, Vypusk IV. S. Petersburg: Tipografiya B. Kirshbauma.

Preble, Paul. 1912. The tarbagan (arctomyc bobac) and plague. Public Health Reports (1896-1970) 27: 31-39. 
Reading, Richard P. et al. 1998. The commercial harvest of wildlife in Dornod Aimag, Mongolia. The Journal of Wildlife Management 62: 59-71.

Ruhlmann, Sundrine. 2018. Dealing with highly contagious animal diseases under neoliberal governmentality in Mongolia. Medicine Anthropology Theory 5: 99-129.

Saveljev, Alexander P. et al. 2014. Contemporary significance of hunting and game animals use in traditional folk medicine in northwest Mongolia and adjacent Tuva. Balkan Journal of Wildlife Research 1: 76-81.

Schaller, George B. Into Wild Mongolia New Haven: Yale University Press.

Scharf, Katie M., Maria E. Fernandez-Gimenez, Batbuyan Batbuyan, and Sumiya Enkhbold 2010. Herders and Hunters in a Transitional Economy: the challenge of wildlife and rangeland management in post-socialist Mongolia. In: Wild Rangelands: conserving wildlife while maintaining livestock in semi-arid ecosystems, edited by J. T. du Toit, R. Kock and J. C. Deutsch (eds), pp. 312-339. Chichester: John Wiley \& Sons, Ltd.

Severi, Carlo. 2015. The Chimera Principle: An Anthropology of Memory and Imagination. Translated by J. Lloyd. Chicago: HAU Books.

Suntsov, V. V. 2017. Recent speciation of plague microbe Yersinia pestis in the heterothermal (heteroimmune) environment of marmot-flea (Marmota siberica-Oropsylla silantiewi): biogeocenotic preconditions and preadaptations. Biology Bulletin Reviews 7 (4): 299-311.

Spyrou, Maria A., et al. 2018. Analysis of 3800-year-old Yersinia pestis genomes suggests Bronze Age origin for bubonic plague. Nature Communications 9 (2234), https://doi.org/10.1038/ s41467-018-04550-9.

Teh, Wu Lien, J. W. Chun, and R. Pollitzer. 1923. Clinical observations upon the Manchurian Plague Epidemic, 1920-21. Epidemiology and Infection 21: 283-306.
Townsend, Susan E. 2009. Estimating Siberian marmot (Marmota sibirica) densities in the Eastern Steppe of Mongolia. Ethology, Ecology \& Evolution 21: 325-338.

Townsend, Susan E., and Peter Zahler. 2006. Mongolian marmot crisis: Status of the Siberian marmot in the eastern steppe. Mongolian Journal of Biological Sciences 4: 37-44.

Vainshtein, Sevyan I. 1979. Nomads of South Siberia: The Pastoral Economies of Tuva. Cambridge: Cambridge University Press.

Winston, Thomas 2011 (film) The Mongolian Marmot. Grizzly Creek Films. Accessed 07/12/2020. https://vimeo.com/26968909.

World Health Organisation, 2020. Interregional meeting on prevention and control of plague. April 2006. Accessed 07/20/2020. https:// www.who.int/csr/resources/publications/WHO_HSE_EPR_2008_ 3 w.pdf?ua $=1$.

Willerslev, Rane. 2007. Soul Hunters: Hunting, Animism and Personhood Among the Siberian Yukaghirs. Berkeley and Los Angeles: University of California Press.

Wingard James R. and Peter Zahler 2006. Silent Steppe: The Illegal Wildlife Trade Crisis in Mongolia. Mongolia Discussion Papers, East Asia and Pacific Environment and Social Development Department. Washington D.C.: World Bank.

Yoshihara, Yu et al. 2009. Effects of disturbance by Siberian marmots (Marmota sibirica) on spatial heterogeneity of vegetation at multiple scales. Japanese Society of Grassland Science 55: 89-95.

Zahler, Peter et al. 2004. Illegal and unsustainable wildlife hunting and trade in Mongolia. Mongolian Journal of Biological Sciences 2: 23-31.

Publisher's Note Springer Nature remains neutral with regard to jurisdictional claims in published maps and institutional affiliations. 